\title{
省エネルギーに関連した居住者の意識・行動・情報欲求のモデル化に関する研究 STUDY ON MODELING OF THE CONSCIOUSNESS, BEHAVIOR AND DESIRED INFORMATION OF OCCUPANTS IN RELATION TO ENERGY SAVING
}

\author{
阿部寛人*1, リジャル H.B. ${ }^{* 2}$, 坊垣和明*3, 宿谷昌則 ${ }^{* 4}$, 三神彩子*5 \\ Hiroto ABE, H.B. RIJAL, Kazuaki BOGAKI, \\ Masanori SHUKUYA and Ayako MIKAMI
}

\begin{abstract}
How much of energy saving effect is possible by residents' behavior must be important. But at least in Japan, it has not yet been made clear. Here in this research, we conducted a questionnaire survey on the residents' interests and lifestyle and thereby made the follow up analysis to figure out how the energy - saving related consciousness, practice, and willingness are connected with each other. It has become clear that the information in relation to the problems to be solved or the willingness for making their levels of life higher is likely to let the respondents take actions.
\end{abstract}

Keywords : Energy saving effect, Behaviour and consciousness, Life style, WEB survey, Condominiums. 省エネルギー効果, 意識と行動, 生活スタイル, ウェブ調査, 集合住宅

\section{1.はじめに}

近年，エネルギー使用量の増加傾向が続く民生部門では大きな削 減目標が設定され，家庭部門では $39 \%$ 減が目標とされている ${ }^{1)}$ 。住 宅の断熱・気密を高めるとともに, エアコンや床暖房などの設備機 器の性能を上げることは重要であるが, 加えて住まい手の行動が省 エネルギー的になることが重要である。電灯を細めに消寸, 室温の 調整を暖房では低めに, 冷房では高めにするなどは住まい手行動の 典型であるが，これらは住まい手に我慢を強いる傾向が強いので, 省エネルギー効果を持続させることが難しいと考えられる。

そこで，省エネルギー行動を誘発し，しかも持続させるための方 法として, 住まい手にエネルギー使用量や生活情報をモニター画面 を通して知らせることにより, エネルギーの適切な使い方を知らせ たり，使い過ぎを認識させるためのホームエネルギーマネジメント システム(HEMS) と呼ばれる仕掛けがある。HEMS を閲覽した人は, 閲 覧する前と比較してエネルギー使用量が小さくなるが, その一方で, HEMS の閲覧頻度は, 導入時点からの時間経過とともに徐々に減少す るという研究結果 ${ }^{2)}$ もるるしたがって, 現段階では HEMS が省エネ ルギー行動を持続させるとは断言できない。

そこで，住まい手の住居内での振る舞いは個々人の自由なのだか ら，エアコンや洗濯機などの設備をコンピューター・インターネッ
トと接続して, 住居内の温度湿度や家電の運転時間を, 快適性を損 なわないように，しかもエネルギー使用量が小さくなるような制御

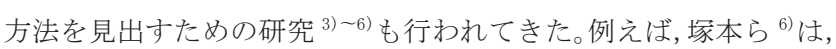
そのような制御機能付きの設備機器による省エネルギー効果がどの 程度あるかを研究している。

一方，制御機能付きの設備機器ではなく住まい手の行動による省 エネルギー効果がどの程度あるかの研究 ${ }^{7) \sim 13)}$ も行われている。上 野 ${ }^{10)}$ らは, 節約意識を促すための情報を与えると, 約 $20 \%$ 省 エネルギー効果のある行動が現れたと報告している。しかし，与え た情報が「節約」のみで，その情報が本当に省エネルギー効果を増 加させたかどうかは不明である。したがって，住まい手の行動が意 識と関係しているのか否か，関係しているのであれば，どのように かを研究した例は少なく, 特に意識の在り様が省エネルギー行動と どのように関係するかを取り上げた例はない。

したがって, 住まい手の行動と意識の関係を研究する必要があ る。特に, 現代生活全般に関して与えられる情報が省エネルギー効 果にどのように関係するかの研究が必要である。

テキストマイニング注 1) の手法を用いて行動変容効果を分析する 研究 ${ }^{14)}$ や, 行動経済学におけるナッジ注 2) に注目した研究 ${ }^{15}$ による と，住まい手に省エネルギーになる行動の情報を提供し啓発すると

\footnotetext{
*1 東京都市大学環境情報学専攻 大学院生

*2 東京都市大学環境学部 - 環境創生学科 教授 $\cdot$ 博士 (工学)

*3 東京都市大学 名誉教授・博士 (工学)

*4 東京都市大学環境学部・環境創生学科 教授·工博

*5 東京ガス(侏) 主幹・博士(学術)
}

Grad. Student, Graduate School of Environmental and Information Studies, Tokyo City University

Prof., Faculty of Environmental Studies, Dept. of Restoration Ecology \& Built Environment, Tokyo City University, Dr.Eng.

Prof. Emeritus, Tokyo City University, Dr.Eng.

Prof., Faculty of Environmental Studies, Dept. of Restoration Ecology \& Built Environment, Tokyo City University, Dr.Eng.

Chief Editor, Tokyo Gas Co., Ltd., Ph.D. 
いう直接的な方法ではなく, 住まい手の心理を探り, 住まい手が省 エネルギー効果のある行動をするための動機を明らかにし, その動 機を刺激することで自然に無理なく省エネルギー効果のある行動を してしまう方法を明らかにしようとする試みが注目されつつある。

これらの研究は, エネルギー使用量削減を住まい手に促すための 意識を発現させる手法を見い出すことを目指したものであるが，こ れらの研究で取り上げられている住まい手への情報は, 省エネルギ 一に特化した内容であり, 住まい手がもともと認識している自身の 生活の課題や願望は含まれていない。

以上のことから，住まい手に敢えて「省エネルギー」を意識させ ることなく, しかし, 実のところ, 省エネルギー効果を創発させる にはどうしたらよいかは重要だと筆者らは考えるに至った。そこで, 筆者らは, 住まい手が省エネルギー効果のある行動をとるためには, 住まい手が日常生活で課題としていることの解決や願望の達成を目 的とした情報提供をきっかけとすれば，そのための行動をとる可能 性はとても高いはずである。そして, 住まい手に与えられる情報が， 日常生活の課題解決や願望達成という目標に直接関係し, しかも工 ネルギー削減につながるような内容とすることができれば，住まい 手は, 省エネルギーを意識せずして, 省エネルギー効果のある行動 をとることができると考えた。

そこで本研究では, 住まい手の課題解決や願望達成のための情報 への興味喚起が期待できる行動を抽出し，その中で省エネルギー効 果と関連のある生活行動を対象に, 住まい手が興味を示してから行 動をとるまでの変容の可能性とその容易度を知るために, 認知（知 っているか), 実践 (実行しているか), 情報取得意欲（関連する情 報が欲しいか）に対する住まい手の意識の在り様を対象とした調査 を行い，省エネルギーと関連する行動が，意識とどのように関係し ているかを分析・検証することにした。

\section{2. 調查の対象と方法}

\section{1 調査の対象}

調查対象は, 現代の都市生活者実態に即した結果を得るために, 近 年戸建住宅と比較し増加傾向にある新築集合住宅への入居者を想定 した。近い将来標準となる先導性の高い建築・設備仕様を有した集 合住宅を供給予定の事業者が, より効率的に入居者を募るために実 施した購入者属性を推定する分析結果注 3 を参照し, 事前に以下の様 にスクリーニング条件を設定し, 解析に十分な数として取得目標サ ンプル数を 1030 とした。(1)男女比 (1: 1), (2)首都圈在住者（1都 3 県), (3)年代 (30 代 : $40 \% ， 40$ 代 : $40 \% ， 50$ 代 - 60 代 : $20 \%$ ), (4)既婚, (5)持ち家集合住宅居住者（住宅購入時価格 3000-7000 万円, 2000 年 以降購入)

調查方法は，インターネットによるアンケート方式 (WEB 調査) を採用し，省エネルギー意識は問わない事とした。調査会社注 ${ }^{4)}$ は， 厳正な調查を実施するため, 品質管理ポリシーを精查し, 決定した。 調查期間は，2014年 12 月 19 日（金）～21日（日）とした。

\section{2 設問分野の決定}

どのような生活行動に興味・関心をもっているか, どのような省 エネルギー関連情報が望ましいかを念頭に, 生活にまつわる情報と して各種市場調查を確認し, 家事の時短, 食生活, 美容, 健康, 節 約, 快適の 6 分野を設定・分類した。6つの分野は, 既往の市場調
查結果 ${ }^{16)}$ 21) から検討・決定し, 分野毎の設問数を 10 とし, 設問数 合計 60 設問とした。

\section{3 設問内容と回答方法並びに分析概要}

\section{3.1 設問内容}

設問は, 省エネ効果のある行動変容を起こす可能性がある情報と して, 直接省エネを訴える情報ではなく, 結果的に省エネに関連す る生活情報・設問を多く設定している点に特徴がある。さらに，回 答者へ省エネを意識させることがないように，アンケート全体の題 目を「ご自身に関するアンケート」として回答者を募り，本設問の 冒頭に「時短・食生活・健康・美容・節約・快適に関する質問に対 してお伺いします。」とした。具体的な省エネとの関連性を付録 1 に，具体的な設問内容を付録 2 に示す。設問（行動）毎に省エネの 関連性は異なる。例えば，「 3 . 健康」の設問 5 付12) や,「4 . 美容」

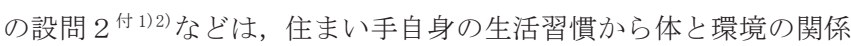
への興味喚起のきっかけとなり，省エネとの関連性は間接的ではあ りながら全く認知されなかった場合より，住まい手自身が，省エネ への関わりへ近づくことを狙い設定している。また，「３．健康」の

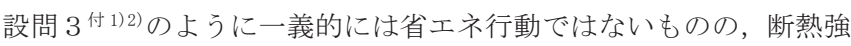
化への気づきに期待するものや，「4 . 美容」の設問 8 付1)2) の行動に より, 加湿器の過剩な利用を低減することになるものは, 行動と省 エネの関わりが比較的強いものである。

\section{3.2 回答方法}

各設問に対し，表 1 の選択肢を設定し，回答を求めた。これらの 選択肢は，先ず，生活情報を知っているか否かという「認知度」，次 に，実行事実または意欲の有無という「実践度」，さらに，関連する 生活情報がほしいか否かという「情報取得意欲度」という，住まい 手の意識と行動の流れを想定して設定している。

Table 1 Categories in the questionnaire

\begin{tabular}{|c|c|c|c|c|c|c|}
\hline & & Recognition & & Behavior & & formation \\
\hline \multirow{4}{*}{ Category } & \multirow{2}{*}{1} & \multirow{2}{*}{ Well-known } & 1 & Practicing & \multirow{2}{*}{1} & \multirow{2}{*}{ Want } \\
\hline & & & 2 & Want to practice & & \\
\hline & $?$ & \multirow{2}{*}{ Unknown } & 3 & Don't practice & \multirow{2}{*}{2} & \multirow{2}{*}{ Don't need } \\
\hline & 2 & & 4 & Not applicable & & \\
\hline
\end{tabular}

\section{3.3 分析概要}

これらの回答結果に基づく分析概要を図 1 に示す。分析の一つは, 生活行動全体について意識と行動の関係を明らかにすること，もう 一点は，意識と行動の差を属性別に分析しようとするものである。

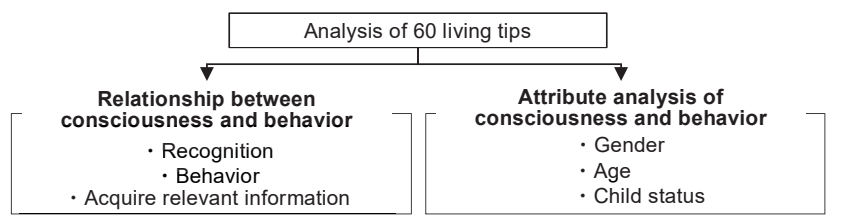

Fig. 1 Outline of analysis of summary

\section{3. 結果}

\section{1 回答者の属性}

回答者の属性を図 2 に示す。男女比（a), 年代（c, d）は, スク リーニング条件通りであり，首都圈在住者，既婚，持家集合住宅居 住者の条件も満たしている。子供の有無 (b) では, 子供有世帯 70\%, 無し世带 30\%である。平均年収は約 840 万円でやや高い所得層 (e) と言える。職種構成（f）は, 会社員 $50 \%$, 専業主婦（夫） $30 \%$, パ ートタイマー $10 \%$ ，となっている。 


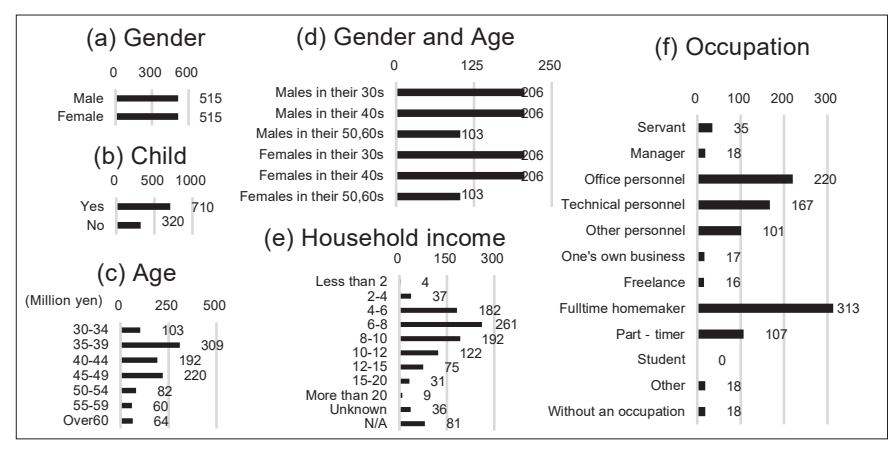

Fig.2 Information of respondents $(n=1030)$

\section{2 意識と行動について}

\section{2.1 回答パターンと回答数について}

図 3 に表 1 で示した選択肢に対する回答パターンと回答数を示す。 60 の設問に対して 1030 人の回答により，61800の回答を得た。 認知度, 実践度, 情報取得意欲度の組合せによる回答パターンは 16 あり, 最多パターンは, 「知っている一実行している一情報がほ しい」が 12377 で全回答の $20.0 \%$, 次いで,「知らない一実行した い一情報がほしい」が 8811 (14.3\%)，「知っている一実行したい一 情報がほしい」が $8254(13.4 \%)$ と，行動意欲を示すパターンが続

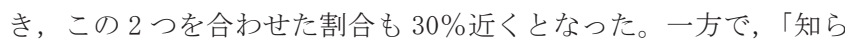
ない一実行しない/当てはまらない一情報は要らない」のパターン が合わせて 9108 で, 14.7\%存在している。認知度, 情報取得意欲 度の回答には考慮せず, 実践度で「実行している/実行したい」を 積極型，「実行しない／あてはまらない」を消極型とすると，前者 が $72 \%$, 後者が $28 \%$ であり, 積極性の高い意識を持つ人が多い傾 向がうかがえる。

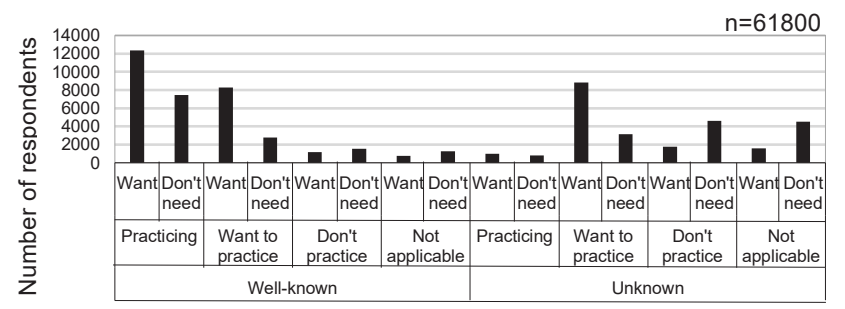

Fig. 3 Distribution of response

\section{2.2 意識・行動と性別の関係}

認知，実践，情報取得意欲の各々について性別との関係を分析 する。図 4〜6では, 性別毎の回答数の差と, 性別の回答比率を比 較し検定を行った結果を示す。認知度, 実践度, 情報取得意欲度 は，性別による有意差が認められた $(\mathrm{p}<0.01)$ 。性別の回答比率の検 定には， $\mathrm{z}$ 検定を用いた。 $\mathrm{z}$ 検定は，正規分布を用いる統計学的検 定法で，標本と母集団との比率の比較が統計学的にみて有意に異な るかどうかを検定する方法である。図 7 では, 「知っている」「知ら ない」の回答において男性と女性の回答率に有意差が認められた場 合に，低い方から高い方へ向かう矢印を示している。具体的には，

「知っている」という回答では，男性の回答から女性の回答に矢印 が向かい，男性よりも女性の方が回答している割合が多いと認めら れた，という事を示している。以降の $\mathrm{z}$ 検定結果の見方も同様であ る。有意差が認められない場合は，矢印は示していない。

認知度, 実践度, 情報取得意欲度は, 性別による有意差が認めら れた $(\mathrm{p}<0.01)$ 「知っている」,「実行している」,「情報がほしい」
では, 女性の方が多く,「知らない」,「実行したい」,「情報は要ら ない」では, 反対に男性の方が多かった。2.2 で分野設定の参照 とした既往の意識調查 ${ }^{22)}$ 29） と比較すると，各分野において女性 の方が男性より意識が高い結果となっている。これら既往の調查結 果は，本調査結果である女性の意識の高さと一致する。

これらの結果より, 省エネルギーに関連した生活行動は、意識が 高い女性を対象とすることが有効と考える。

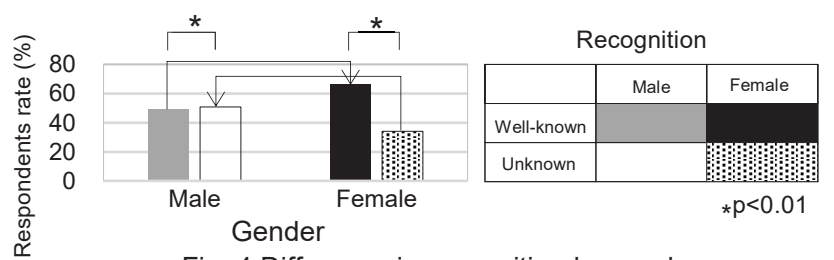

Fig. 4 Difference in recognition by gender

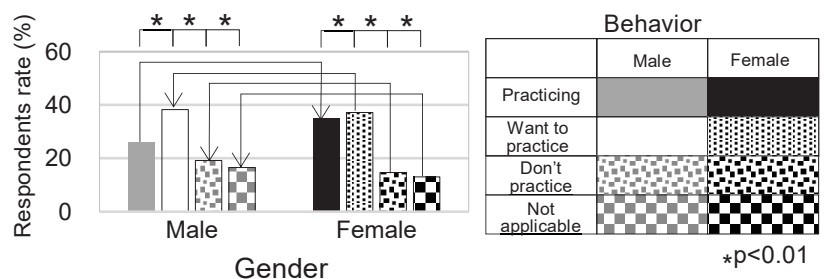

Fig. 5 Difference in behavior by gender

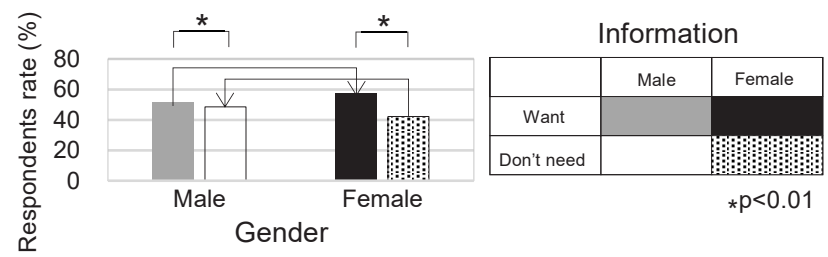

Fig. 6 Difference in information by gender

\section{2.3 意識・行動と年代の関係}

認知，実践，情報取得意欲と年代との関係について分析する。図 7〜9 では, 年代別の意識, 行動の差を示す。年代間の比率を比較 し, $\mathrm{z}$ 検定を行った結果も示す。

認知度の年代間の比較では, 高年代ほど認知度 - 実践度ともに高 く 60 才以上が最高で, 最低の 30 代よりもそれぞれ約 $10 \%$ 高くなっ ている。一方で, 実行意欲（実行したい）は実践度とは逆に，30 代 で最も高くなっている。情報取得意欲度では，全ての年代で「情報 がほしい」が多かったが, 50 代が他の年代に比べて「情報がほしい」 割合がやや高い傾向であった。前述の既往の年代別意識調査 ${ }^{22)}$-32) では，家事の時短と快適については意識の年代差は見られない。食 生活と健康については年代が高くなるにつれて意識が高くなってい るが，特に 50 代が他の年代と比べて高いことは，本調查結果で「情 報がほしい」の割合が 50 代でやや高いことと一致する。美容と節約 については 20 代が最も高く, 年代が高くなるにつれて低くなる。既 往調查と本調查の結果を総合すると, 生活行動への意識と年代の関 係については分野によって異なる傾向があることが示唆される。

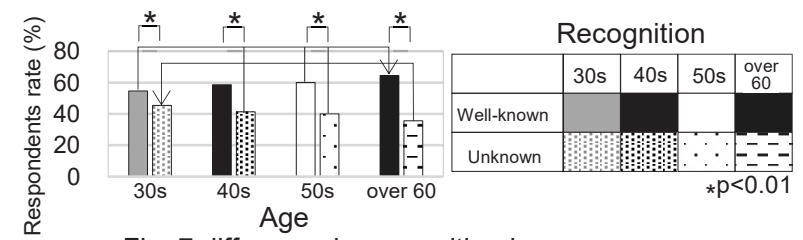

Fig. 7 difference in recognition by age 


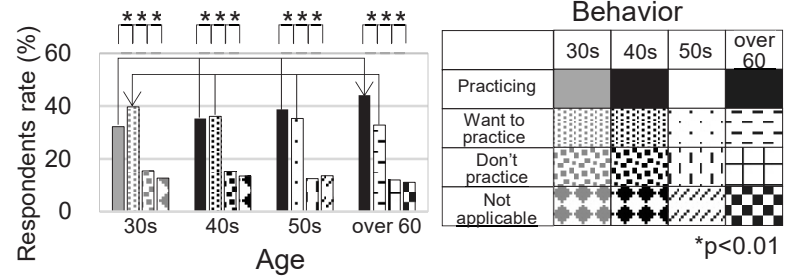

Fig. 8 Difference in behavior by age

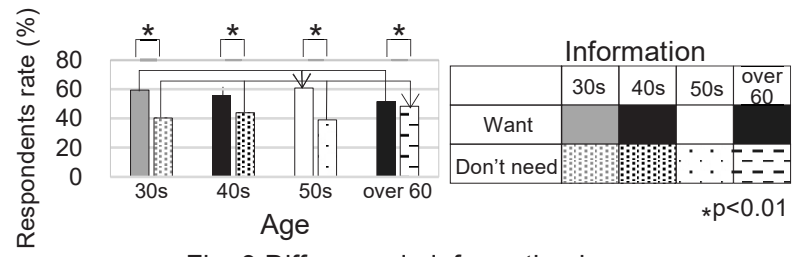

Fig. 9 Difference in information by age

\section{2.4 意識・行動と子供の有無の関係}

認知, 実践, 情報取得意欲の意識・行動と, 子供の有無との関係 を分析する。図 10〜12 では, 子供の有無毎の回答差を示し, 回答 数の比率を比較し, $\mathrm{z}$ 検定を行った結果を示す。

認知度, 実践度, 情報取得意欲度は, 子供の有無による有意差が 認められた $(\mathrm{p}<0.01)$ 。子供がいる世帯の方が, 認知度, 実践度とも に高く, 一方で, 実行意欲（実行したい）と情報取得意欲（情報が ほしい) は，子供がいない世帯の方が高かった。

既往の子供の有無別意識調査 ${ }^{29)}$ ，33) 39) によれば，家事の時短， 食生活, 節約, 快適については, 子供なしょり, 子供ありの方が意 識が高い。一方, 健康管理の実践度と美容の意識は, 子供ありよ り, 子供なしの方が高い。このように既往調査では, 家事の時短, 食生活, 節約, 快適の 4 分野と健康, 美容と 2 分野では, 異なる傾 向がみられた。本調查結果では, 子供の有無による認知度・実践素 度, 情報取得意欲度が異なることを示したが, 分野別の分析には至 っておらず，より詳細の分析が今後の課題と言える。

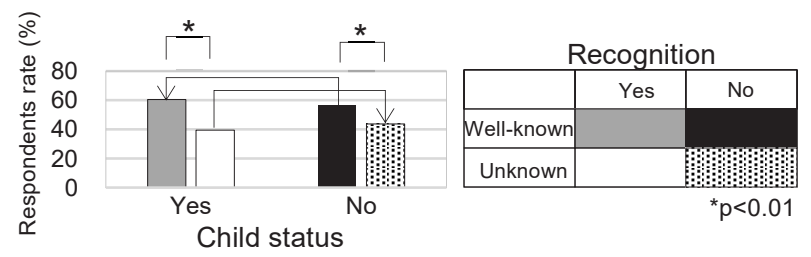

Fig.10 Difference in recognition by child status

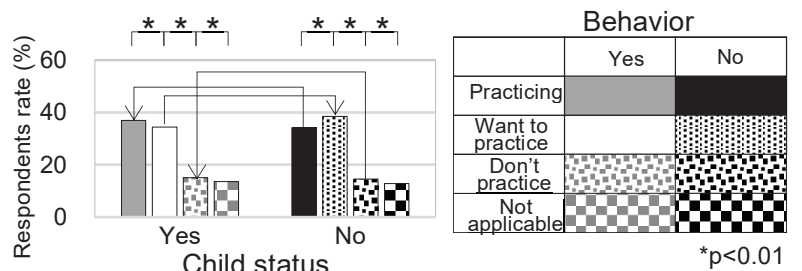

Child status

Fig.11 Difference in behavior by child status

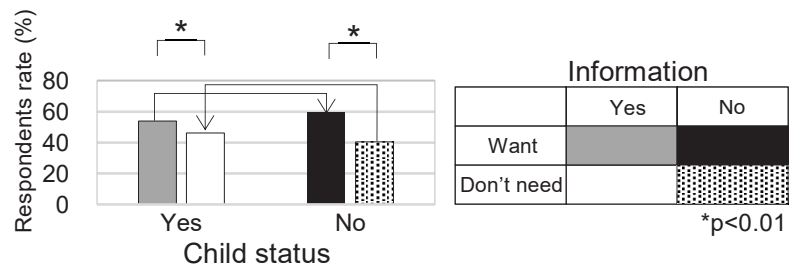

Fig.12 Difference in information by child status
4. 省エネルギーに関連する意識・行動・情報欲求のモデル化

以上の結果より, 省エネルギー効果のある行動に係る意識や実践 等について以下のような結果が得られた。

1）知っている人の中では，実行している人が最も多い。

2）知らない人の中では，実行したい人が最も多い。

3）実行している，実行したい人は，情報取得意欲が高い。

4）知っている人，知らない人共に情報がほしい。

1）４）の結果から考えられる, 意識と行動の関係について整理し,

意識・行動・情報欲求モデルとして可視化し, 図 13 に示寸。

前章3.2.1 の結果から, 認知度, 実践度, 情報取得意欲度の各々 の選択肢同士を結び，関係を表す。図中，回答数の多い割合の関係 を太線で示す。明らかに意識に差がある傾向は，太い実線と太い点 線に大別される。前者（太実線 4 パターン）を「意識行動積極型」, 後者 (太点線 2 パターン) を「意識行動消極型」と呼ぶことにする。

意識行動積極型は, 全体の約 $60 \%$ で過半を超える回答数であり, 意識行動消極型は約 15\%である。3.2.1 で既に示したが，積極型を 「実行している／実行したい」(細実線含む)，消極型を「実行しな い/あてはあらない」(細破線含む) の全てにそれぞれ拡張すると， 前者は約 $72 \%$ ，後者は約 $28 \%$ となる。

意識行動積極型の内, 「知っている-実行している-情報がほしい」 のパターンは，既に実行済なだけでなく，情報取得によって，省エ ネ効果のある行動種類を拡張させる意欲がある可能性が考えられる。

「知らない一実行したい一情報がほしい」のパターンは，アンケー トによって知り得た生活情報に興味哃起し，実行意欲が湧き，関連 情報の取得意欲を持つ, という一連の意識と行動の変容プロセスを 形成する可能性を示唆している。

「知っている-実行したい一情報が欲しい」のパターンは，実行は していないが実行に移る確度が極めて高いと推察される。

一方, 拡張した意識行動消極型は全体の $28 \%$ 存在し，この回答者 に行動変容を促すのは難しいと考えられるが，この中で情報が欲し い人の割合が約 $9 \%$ あり, これらの人たちに何らかの興味喚起を促 す情報を提供することは可能である。問題は残りの $19 \%$ であり, こ れらの人たちへの働きかけが課題と言える。

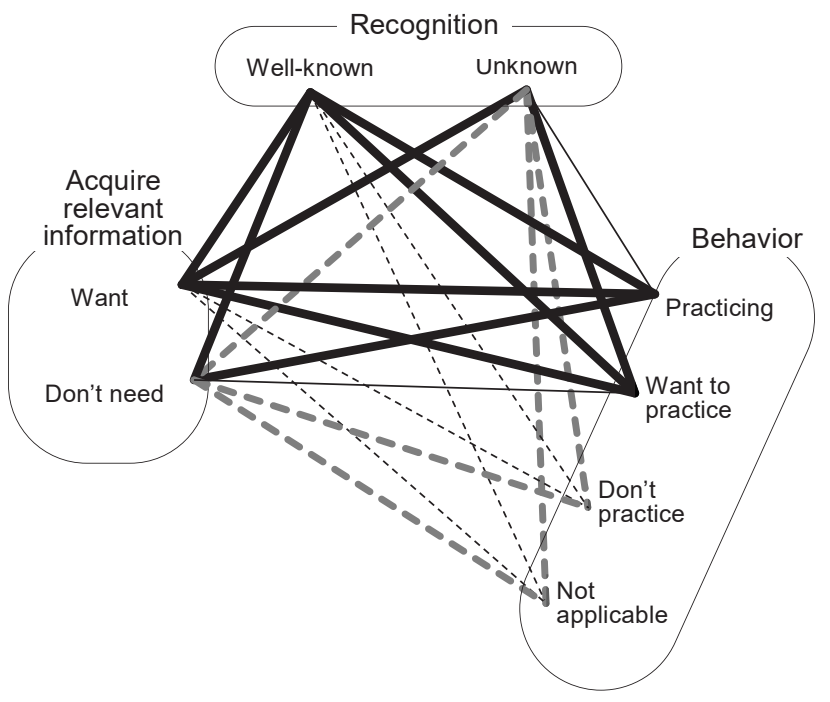

Fig. 13 Model of consciousness to behavior 


\section{1 モデルにおける性別の特徵}

省エネルギー効果のある行動に係る意識・実践等について以下の ような男女別の特徴が得られた。

1）男女それぞれ，「意識行動積極型」の割合が多い。

2）男女の比較では，「意識行動消極型」の男性の割合が多い。

3）「知っている」，「実行している」，「情報がほしい」は，女性が 多い。

図 13 をベースとして，1）３）の結果から考えられる，男女別の 意識と行動の関係について整理し, 図 14 として属性別に意識と行 動の関係を具体化した。3.2.2 の分析結果（図 4～6）に対応した選 択肢にそれぞれ着色し, 回答数を着色した帯の横幅で表している。

これらの結果から考え得る情報提供の在り方を示す。

1）女性は認知度, 実践度が高く, さらに情報を欲しており, 住居 内での生活密着度の高い情報提供が有効

2）男性は，認知度は低いが実行意欲はあるので，住居内生活行動 への興味喚起を促す情報提供が有効

1) は, 従来の生活スタイルの延長上で考えられるが, 認知度に乏し い男性に対しても, 現代の生活スタイルが変化してきていることを 起点に, 興味喚起を引き起こす適切で有効な情報提供のあり方が提 案できると考える。これらの結果は, 生活密着度が高い設問である ことから, 女性の方が生活行動全般に対して日常から密着度が高い 可能性があることを示唆している。また，女性は，情報取得意欲も 高いことから生活行動をより良くしようとする意思がうかがえる。

一方で，男性の「実行したい」という回答数の高さは，生活行動に 関与したい潜在的な意識が表れたと考えることが可能であり，その ような意識に訴えかけることの有効性が示唆される。

\section{2 モデルにおける年代別の特徵}

年代別について以下のような結果が得られた。

1）全ての年代それぞれで，「意識行動積極型」が最も多い。

2）30 代は，他の年代と比べて「知らない」の割合が最も高い。

3）30 代，40 代で，「実行したい」が最も多い。

4）全ての年代で，「情報がほしい」が多い。

5）50 代が他の年代に比べて，「情報がほしい」の割合が高い。

図 13 をベースとして，1）～5）の結果から考えられる, 年代別の意 識と行動の関係について整理し, 図 15 に示す。表記方法は, 男女 別と同様である。

これらの結果から考察できることを次に示す。

1）生活経験年数の差に拘らず，情報取得意欲が高い。

2） 30 ・40 代で, 実行意欲が高いことから行動変容の可能性が高い。

1)について, 生活行動の認知と実践には, 生活経験年数の影響が 認められる一方で, 50 代の情報取得意欲が高いことから, 単に生活 経験が長くなることで情報取得意欲が低下寸るものではないことが わかる。これは，年代に応じて生活で直面する課題が変化し，その 都度, 新しい生活行動へ対応する必要性が生じ, 実践する楽しさを 経験した結果に基づくと考えることは可能である。

2)については, この世代が, 家族の誕生や成長など変化の多い時 期であるため，他の世代と比較して未知・未経験ないしはそれに近 い状況に置かれることが多く, 常に新しい行動や情報等への意欲が 高く, それが行動変容に結び付けられるのではないかと考えること は可能である。

\section{3 モデルにおける子供有無別の特徵}

子供の有無別に生活行動に対する意識・行動について以下のよう な結果が得られた。

1）子供のいる，いない世帯それぞれ，「意識行動積極型」の割合 が最も多い。

2）「実行している」の割合は，子供のいる世帯の方が多い。

3）「実行したい」の割合は，子供がいない世帯の方が多い。

4）情報がほしい人の割合は，子供がいない世帯の方が多い。

図 13 をべースとして，1） 4)の結果から考えられる, 年代別の意 識と行動の関係について整理し, 図 16 に示寸。表記方法は, 男女別 と同様である。

子供がいる世帯の情報取得意欲については，必要としない割合が 多い（図 12）ことから，興味喚起を促す情報の在り方の吟味が必要 と思われる。子供のいない世帯については, 意識積極型の中でも実 行したい割合が多い (図 11) ことから省エネルギー効果のある生活 行動へと促すことが可能と考えられる。これらの結果から考察でき ることを示す。

1）子供がいる世帯では生活経験の多様さ・豊かさの中で認知度, 実践度等が高くなっている

2）子供がいない世帯では，新しい生活経験への試み意欲が高い

1)については，子供の誕生で家族構成が著しく変化し，通常の生 活情報だけではなく, 子育てに関する情報の必要性が強く, 子供の 存在が行動変容を促寸機会として大きいと考えることは可能である。 一方で，情報取得意欲については，子育てに忙しくて時間的余裕が ない等とも考えられるので, 詳しく要因を分析することは今後の課 題である。

2)については，子供がいない世帯では生活時間にも余裕があると 考えられ，実行意欲・情報取得意欲の高さから，新しい行動への試 み意欲が高いと考えることは可能である。但し，共働きで忙しく認 知や実践に至らない, 結婚して時間のたっていない状況では, 生活 行動全般が未経験なために認知度, 実践度が低い, などが考えられ る。これらを実証し, 適切な情報提供のあり方に結び付けていく必 要があると考える。

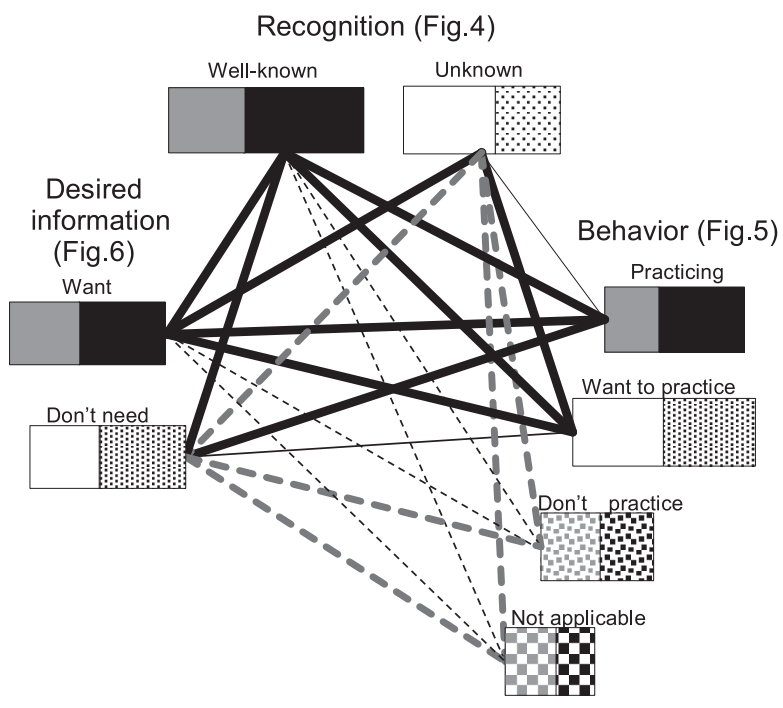

Fig. 14 Model of consciousness to behavior by gender 


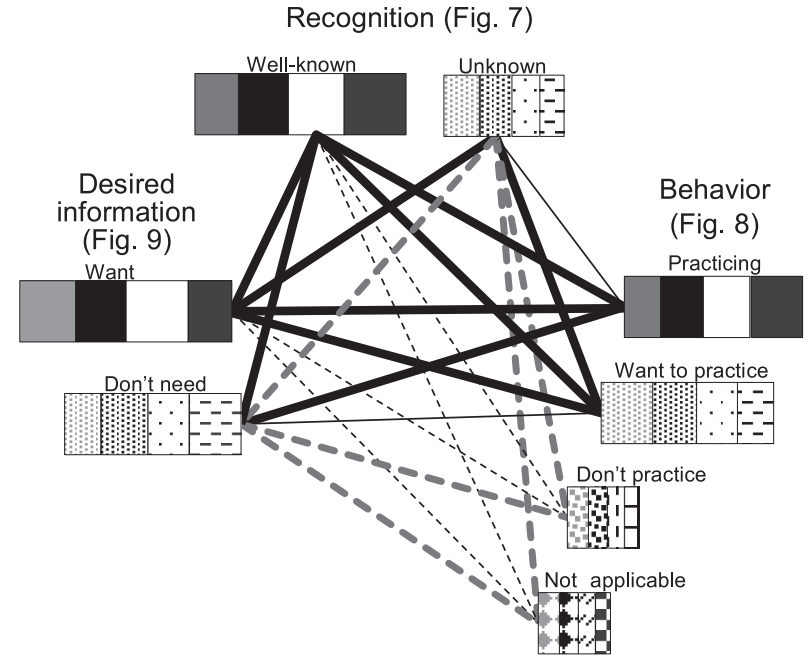

Fig. 15 Model of consciousness to behavior by age

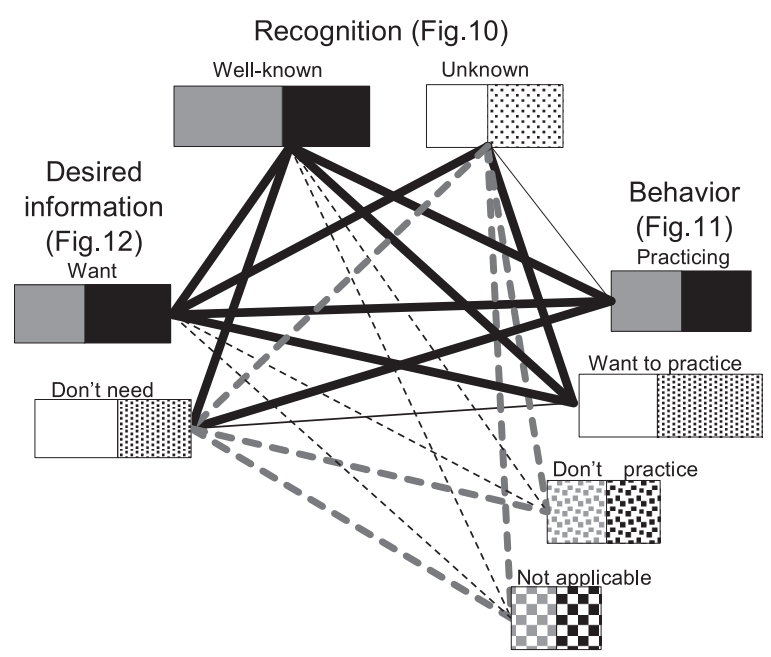

Fig. 16 Model of consciousness to behavior by child

\section{5. おわりに}

本研究では, 省エネルギーに関連する生活情報が, 住まい手にと って有効かどうかを明らかにするために, 現代生活全般にわたる行 動の情報提供に関寸る意識についてアンケート調查を行ない, その 結果を分析した結果，次のことが明らかとなった。

1）住まい手の課題解決や願望達成に関する情報を提供すること は, 行動する意欲を高め得る。(1)認知度が高ければ実践度も高く, 情報取得意欲も高い。(2)認知度が低くても実践意欲は高く, 情報取 得意欲も高い。(1)に該当する回答者は, 現在の自身の生活をより向 上させるために情報取得の意欲があり, (2)該当する回答者は, 知 らなかった情報が，本アンケートによる情報提供により認知された ことで，実践意欲と情報取得意欲が湧いた，と言える。したがっ て, (1), (2)の回答者ともに, 省エネルギー効果のある行動へ誘導で きる可能性がある。

2）女性は，認知度・実践度・情報取得意欲度が高い。男性も実行 したいという意欲が高いことは確認された。したがって, 男性も何 らかのきっかけがあれば, 行動が現われ始めることに期待できると 思われる。意欲を高める情報の内容は, 女性には, 生活に密着した 情報提供が有効である一方, 男性には, 興味喚起を促す分野や内容 を明らかにする必要があることがわかった。
3）認知度・実践度は年代が高くなるにつれて高くなる傾向がある が，実行意欲は若年層の方が高いことがわかった。情報取得意欲度 は，60 歳以上になるとやや低かった。情報取得意欲に年代の差は ほとんど見られなかったので，年代を問わず，情報提供は有効であ ると言える。

4）子供がいる人の方が，子供がいない人より認知度・実践度は高

く，子供がいない人は子供がいる人より実践意欲・情報取得意欲が やや高かった。子供がいない人への情報提供の有効性が高いことは 明らかである。

以上により, 省エネルギーに関連した住まい手の課題解決や願望 達成に関する情報提供によって, 行動する意欲を高める可能性があ ることがわかった。したがって, 本研究で試みた住まい手の意識・ 行動・情報欲求の関係性の分析に基づいて行動意欲を促す情報提供 の在り方を明らかにすることで，快適で豊かな暮らしを犠牲にする ことなく, エネルギー使用量の削減が誘導できる可能性を見出した と考える。また, 属性別に認知, 実践, 情報取得意欲に有意な差を 見出し，それらのモデル化により，属性別の行動変容の容易度を測 るきっかけを示した。今後は，属性に合わせた情報提供の在り方や 具体的な情報内容を明らかにすることが課題であると考える。

\section{謝辞}

本研究は東京都市大学と(侏東急不動産 R\&Dセンターおよび (一社) 日本ガス協会の研究の一環として実施したものである。関係各位の ご協力に深甚の謝意を表する。

\section{参考文献}

1) Nagura, Y.: On future global warming countermeasures of Japan that received the COP 21 agreement (Global Warming Forum), pp. 1-13, 2015.12 (in Japanese)

名倉良雄: COP21 合意を受けた日本の今後の地球温暖化対策について, 地球温暖化フォーラム, pp. 1-13, 2015.12

2) Nodomi, A. Hojo, T. Nakajima, H.: Energy management using HEMS in housing complex (Part2) Analysis of energy saving effect by HEMS, Summaries of Technical Papers of Annual Meeting, Architectural Institute of Japan, Environmental Engineering-I, pp. 983-984, 2005.7 (in Japanese)

納富昭光, 放生孝弘, 中島裕輔: 戸建住宅団地における HEMS を活用した エネルギー需要マネジメントに関する研究(その 2) HEMS による省エネル ギー効果の分析, 日本建築学会大会学術講演梗概集, 環境工学-I, pp. 983984, 2005.7

3) Miyazawa, S. Ishikawa, M. Hayama, T. Okamoto, K. Sekiya, K. Sugimura, H. Okuyama, T. Isshiki, M.: Development of next-generation HEMS services - utilization of the data from smart electric power meters, Research report of information processing society of 2015, pp. $1-4,2015.5$ (in Japanese)

宮澤重明，石川誠弥，葉山拓哉，岡本健司，関家一雄，杉村博，奥山武彦，

一色 正男: 新世代 HEMS サービスの開発〜スマートメータのデータ活用

$\sim, 2015$ 年度情報処理学会研究報告, pp. 1-4, 2015.5

4) Kashimoto, Y. Hata, K. Nakagawa, A. Suwa, H. Fujimoto, M. Arakawa, Y. Shigezymi, K. Komiya, K. Konishi, K. Yasumoto, K.: A living activity recognition system based on power consumption of appliances and energy harvesting pir and door sensors, Journal of information processing society of japan, pp. 409-418, 2017.2 (in Japanese) 柏本幸俊, 秦恭史, 中川愛梨, 諏訪博彦, 藤本まなと, 荒川豊, 繁住健哉, 小宮邦裕, 小西健太, 安本慶一: エナジ八ーベスト焦電型赤外線・ドア開 閉センサと家電消費電力に基づいた宅内生活行動認識システム 情報処理 学会論文誌, pp. 409-418, 2017.2

5) Ueda, K. Tamai, M. Arakawa, Y. Suwa, H. Yasumoto, K.: A living 
activity recognition system based on power consumption of appliances and inhabitant's location information, Journal of information processing society of japan, pp. 416-425, 2016.2 (in Japanese) 上田健揮, 玉井森彦, 荒川豊, 諏訪博彦, 安本慶一: ユーザ位置情報と家電 消費電力に基づいた宅内生活行動認識システム, 情報処理学会論文誌, pp416-425, 2016.2

6) Tsukamoto, M. Fujita, N. Yoshihisa, T.: A framework of rule controlled ubiquitous system for in-home EoD, Proceedings of the IPSJ Kansai chapter branch proceedings, F-17, 2011.9 (in Japanese) 塚本昌彦, 藤田直生, 義久智樹: 家庭内 $\operatorname{EoD}$ のためのルール制御型ユビキ タスシステムのフレームワーク，平成 23 年度情報処理学会関西支部支部 大会講演論文集, F-17, 2011.9

7) Nakamura, S. Hiromori, A. Yamaguchi, H. Higashino, T. Yamaguchi, Y. and Shimoda, Y.: Living behavior recommendation system utilizing sensing in smart house, Multimedia distributed cooperation and mobile symposium 2014 proceedings, pp.1557-1566, 2014.7 (in Japanese) 中村笙子, 廣森聡仁, 山口弘純, 東野輝夫, 山口容平, 下田吉之：スマート 八ウス内センシングを活用した生活行動推薦システム, マルチメディア分 散協調とモバイルシンポジウム 2014 論文集, pp.1557-1566, 2014.7

8) Kashimoto, Y. Ohno, A. Tamai, M. Yasumoto, K.: Sensing energy-saving activities for smart energy consumption, Proceedings of multimedia communication and distributed processing workshop, pp. 124-129, 2012.10 (in Japanese)

柏本幸俊, 大野敦司, 玉井守彦, 安本慶一: スマートなエネルギ一利用に 向けた生活の知恵センシングシステム, マルチメディア通信と分散処理ワ ークショップ, pp. 124-129, 2012.10

9) Morita, M.: Verification of actual state of energy saving behavior and effective means of information means in household sector - Analysis using survey data in Soka city, Saitama prefecture before the earthquake -, Environmental science journal, pp. 161-170, 2017 (in Japanese)

森田 稔: 家庭部門における省エネ行動の実態と情報的手段の有効性に関 する検証 震災以前の埼玉県草加市でのサーベイデータを用いた分析, 環 境科学会誌, pp. 161-170, 2017

10) Ueno, T. Tsuji, K.: Energy Saving activities induced by an energy consumption information system in the residential houses, Proceedings of the academic lecture of the society of air and sanitation engineering, pp. 1497-1500, 2005.7 (in Japanese)

上野 剛, 辻 毅一郎：エネルギー消費情報提供システムによる家庭内での 省エネルギー行動に関する分析 空気調和・衛生工学会学術講演会論文集, pp. 1497-1500, 2005.7

11) Mikami, A. Nagao, K.: Analysis of energy conservation behavior change effect and energy saving behavior obstruction factor due to "energy conservation behavior degree of practice" and "degree of interest in the environment", Japanese home economics education society meeting seminar research presentation abstract, p. 80, 2015 (in Japanese)

三神彩子, 長尾慶子: 省エネ行動実践度と環境への関心度の違いによる省 エネ行動変容効果 及び省エネ行動阻害要因の分析, 日本家庭科教育学会 大会・例会・セミナー研究発表要旨集, p. 80, 2015

12) Mikami, A. Akaish, N. Hisamatsu, Y. Nagao, K. : Environmental and energy saving behavior transformation effect by seminars as home garbage weight loss support measures, Summary of research presentations by the Japanese home economics association, p. 66, 2015 (in Japanese)

三神彩子, 赤石記子, 久松裕子, 長尾慶子：家庭ごみ減量支援策としての 講習会による環境・省エネ行動変容効果, 日本家政学会研究発表要旨集, p. 66,2015

13) Araki, Y. Sasahara, M. Mikami, A. Nagao, K.: Possibility of transformation of energy conservation behavior through water-saving behavior during dishwashing, Japanese home economics education society meeting · seminar research presentation abstract, p. 73, 2014 (in Japanese)

荒木葉子, 笹原麻希, 三神彩子, 長尾慶子: 食器洗浄時の節水行動を通し た省エネ行動変容の可能性, 日本家庭科教育学会大会・セミナー研究発表 要旨集, p. 73,2014
14) Kobayashi, T. Ohnuma, S. Mori, Y.: A text-mining-based investigation of longitudinal energy saving behavior: A case study of asahikawa "Ene-Eco project", Papers on environmental information science, pp. 37-42, 2014 (in Japanese)

小林翼, 大沼進，森康浩：テキストマイニングを用いた省エネルギーへの 態度・行動の質的変化 旭川 Ene-Eco プロジェクトの事例研究 環境情報 科学論文集, pp. 37-42, 2014

15) Komatsu, H. Nishio, K.: Recent developments of information provision policy to promote energy conservation and power saving aiming to appeal to intuition, Behavioral economics volume 6, pp. 97100, 2013 (in Japanese)

小松秀徳，西尾健一郎：直感への訴えかけを狙って省エネルギー・節電を 促進する情報提供方策の近年の動向,行動経済学第 6 巻, pp. 97-100, 2013

16) Softbrain Field Co., Ltd.: Survey on housework situation of housewives, 2012.12 (in Japanese)

ソフトブレーン・フィールド株式会社：主婦の家事実態調査, 2012.12

17) Consumer Agency: Consumer white paper 2014, 2014. 6 (in Japanese) 消費者庁：平成 26 年度消費者白書, 2014.6

18) Ministry of Health, Labor and Welfare: Survey on health consciousness, 2014.2 (in Japanese) 厚生労働省：健康意識に関する調査, 2014.2

19) My Voicecom Co., Ltd.: Beauty awareness and behavior survey (2nd) 2015.7 (in Japanese)

マイボイスコム株式会社：美容意識と行動調査（第 2 回）, 2015.7

20) Asahi Group Holdings Co., Ltd.: Consciousness Survey on Conservation, 2016.2 (in Japanese)

アサヒグループ HD 株式会社：節約に関する意識調査, 2016.2

21) Ministry of Land: Infrastructure, Transport and Tourism, Living life survey, 2013.12 (in Japanese)

国土交通省：住生活総合調査, 2013.12

22) Cabinet Office: User's intention survey for inspection and evaluation of declining birthrate measures via the internet, etc. [HTML Version] Chapter 24 . (4) Share of share of couples' Housework and Child Care 2009.11(in Japanese)

内閣府：インターネット等による少子化施策の点検・評価のための利用者 意向調査[HTML 版] 第 2 章 4.(4)夫婦の家事・育児の分担割合, 2009.11

23) Ministry of Agriculture, Forestry and Fisheries: Awareness survey on food education 3.1. (1). (2), 2016.11(in Japanese)

農林水産省：食育に関する意識調査 3.1.(1).(2), 2016.11

24) Ministry of Health, Labor and Welfare: Low birthrate and elderly society survey study project report (Health consciousness survey edition)2014, 3 (in Japanese) 厚生労働省：少子高齢社会等調查検討事業報告書（健康意識調査編）, 2014. 3

25) Research institute of Japan Efficiency Association: Health needs survey 2015, 2016.1 (in Japanese)

株式会社日本能率協会総合研究所：健康ニーズ調査 2015, 2016.1

26) Macro Mill Inc.: Questionnaire on health consciousness, 2003.3 (in Japanese)

株式会社マクロミル：健康意識に関するアンケート, 2003.3

27) Recruit lifestyle Co., Ltd.: Beauty census 2015 second half perception survey (Beauty consciousness edition) 2015.12 (in Japanese) 株式会社リクルートライフスタイル：美容センサス 2015 年下期意識調査 (美容意識編), 2015.12

28) Hakuhodo Institute of Life Research: Life survey (Beauty No. 1248), 2016 (in Japanese) 博報堂生活総合研究所：生活定点調査（美容 No.1248）, 2016

29) IT Realize Co., Ltd.: Survey on actual savings, 2017.5 (in Japanese) アイ・ティ・リアライズ株式会社, 節約についての実態調査, 2017.5

30) LIXIL Inc., "Living life that I want to realize" questionnaire survey, 2017.10 (in Japanese)

株式会社 LIXIL：実現したい暮らしアンケート調査, 2017.10

31) Research Institute of Japan Efficiency Association, Inc.: Research on housework style, 2016.9 (in Japanese)

株式会社日本能率協会総合研究所：家事スタイルに関する調査, 2016.9

32) Asahi Group Holdings Co., Ltd.: Weekly questionnaire survey, No. 
620 times, 2017.2 (in Japanese)

アサヒグループホールディングス株式会社：毎週アンケート調査，第 620 回, 2017.2

33) Belle Maison Lifestyle Institute: Questionnaire survey on your current feelings, 2016.10 (in Japanese)

ベルメゾン生活スタイル研究所：現在のあなたのお気持ちについてのアン ケート調査, 2016.10

34) Recruit Marketing Partners, Inc.: Couple relationship survey, 2017.7 (in Japanese)

株式会社リクルートマーケティングパートナーズ：夫婦関係調査, 2017.7

35) Hirasawa, Y. Oyama, Y. Araki, Y. Fujii, N. Wakabayashi, C.

Yoshinaka, Y. Fukuda, R. Tanaka, N.: Working women's dietary survey

$\sim$ Relationship with the presence of children, age of children $\sim$, Journal of the japan occupational and disaster medical association JJOMT Vol. 62 No. 6, pp. 399-403, 2014.5 (in Japanese)

平澤 芳恵, 大山由美子, 荒木由美子 藤井 夏美, 若林 智佳, 吉中由美子, 福田 里香, 田中 直彦: 働く女性の食生活調査〜子供の有無, 子供の年齢 との関連〜, 日本職業 - 災害医学会会誌 JJOMT, Vol.62 No.6, pp. 399$403,2014.5$

36) Tokyo Metropolitan Life Culture Bureau: Public opinion survey on dietary habits and education, 2014.10 (in Japanese) 東京都生活文化局：食生活と食育に関する世論調査, 2014.10

37) Dai-ichi Life Economic Research Institute Inc.: Survey on anxiety and preparation in the 40s and 50s, 2014.12 (in Japanese)

株式会社第一生命経済研究所： $40 \cdot 50$ 代の不安と備えに関する調査, 2014.12

38) Neo Marketing Inc.: Women's consumer behavior / lifestyle survey, 2016.8 (in Japanese)

ネオマーケティング株式会社：女性の消費行動・ライフスタイル意識調 査, 2016.8

39) Major Seven secretariat: New condominium portal site MAJOR 7 the 4th condominium trend survey, 2006.1 (in Japanese)

メジャーセブン事務局：新築マンションポータルサイト MAJOR 7 第四回 マンショントレンド調査, 2006.1

注

注1) テキストマイニングとは，大量のテキストデータから新たな事実や傾 向を発見することを支援する技術であるという。小木しのぶ：テキストマ イニングの技術と動向, 計算機統計学 第 28 巻 ・第 1 号 2015, pp. 31-40

注2) ナッジ(nudge)とは, 直訳すると「ひじで軽く突く」という意味であ る。行動経済学や行動科学分野において, 人々が強制によってではなく自 発的に望ましい行動を選択するよう促す仕掛けや手法を示す用語として用 いられている。これは，その物や現象の良しあしに対する客観的な絶対評 価よりも，物事をどう感じるかという主観的な比較評価により人間の選択 が左右される心理傾向を利用したものである。正木宏長：情報を用いた誘 導への一視座一行動経済学, ナッジ, 行政法一, 立命館法学 2015 年 4 号 (362 号)

注3) 国土交通省 住宅・建築物省 $\mathrm{CO}_{2}$ 先導事業に採択された東急グループで 取り組む省 $\mathrm{CO}_{2}$ 推進プロジェクト第一号物件 ブランズシティ品川勝島の 購入者推定属性分析を参考とした。

注4) 株式会社マクロミル（英文社名：Macromill, Inc.)

付録 1 認知度・践度・情報取得意欲度に関する設問と省エネ関連性

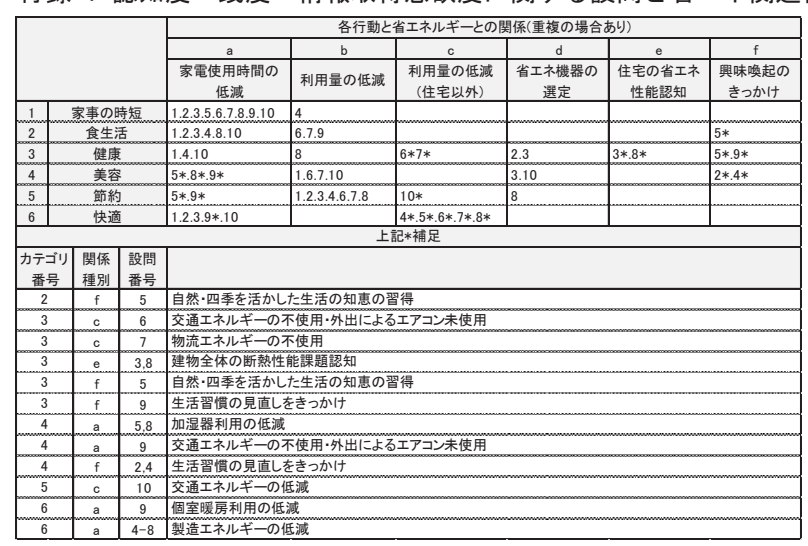

付録 2

認知度・践度・情報取得意欲度に関する設問例と具体的な設問内容一覧

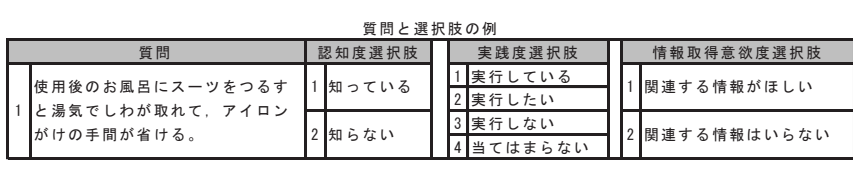

質問一筧

1 使用後のお風呂にスーツをつるすと湯気でしわが取れて、アイイロンがけの手間が省ける

乾燥機にかけるとき，乾いたバスタオルを1枚ー緒に入れると乾燥時間が短縮できる

マットはまっすぐより斜めにずらして干すと早く乾くので,浴室乾燥や室内乾燥時に時間短縮できる。

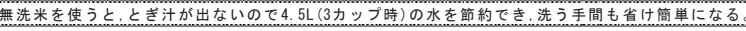

なんとなく垍慣で回している洗濯機、容量に合わせてまとめ洗いをすることで洗濯回数が減らせる。

部屋を片付けてから掃除するた゚けで、揞除機がけら分短縮、集麼パックを適宜交換で効率もアップする。

やかんや銅での加熱、タイマーを上手に使えば加熱し過きをを防げて、時間も上手に使える。

食器洗い乾燥機は使う水の量が1/6,さらに洗っている時間に他の家事を済ませることができる。

ガスコンロの自動炊飯キーなら,お鍋の直火炊きが20分で炊きあがる。食びる量をその都度炊いておいし く、しかも早くできる。

10浍涷グラタンや椧涷ビザは、オーブントースターよりもグリルで温めると早くおいしく仕上がる。

内で卵は, 水から卵を入れて沸滕したらすぐに火を止め,ふたをして5分で半熟卵が,もっと長く置けば完熟

卵ができる。アルデンテパスタも同じようにできる。

ガスコンロのグリルでプレートを使ってトーストを塂くと、約2分で外はパリッと中はもちっとした契茶店

のようなトーストができる。

フライパンの上で15cmの円を書いたら大さじ1杯の油, 塩小さじ1/2なら3本指でつまんで4回，目分量を賞え

たら料理が早く上手になる

4 䔺物料理で落し蓋をすると調理時間が半分に、さらに普通の調理時にも蓋を活用すると熱が上手に使える。

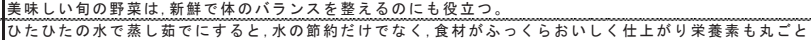

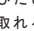

炎をなべ底からはみ出さないようにすると、鍋の取っ手が熱くなったり焦げる心配もなく、省エネになる。

やかんや鍋を洗った後、銷底についた水滴を拭き取ってから火にかけると、カス量の節約と加䓡時間の短縮 になる。

洽蔵庫は容量に合わせて適切な設定温度(例えば柿か中)にすると,節電と上手な保存ができる。 肉や魚をグリルで調理する時, 付け合せの野莱も同時に焼くと、味が凝縮され美味しく時間も節約できる。

的健康

床暖房は, 床からの放射熱で壁/天井の表面温度も上がり,足元が暖かいので"頭寒足熱”゙の快道な環境がで きる。

寒い冬に裸になる脱衣耊や浴室を暖房すると,ヒートショックを和らげ体への顀担が減らせる

お風吕から上がる前に、足元を中心にシャワーを使ってマッサージすると, 風员上がりの温かさが持続す

4 お。

5 ユネスコ無形文化遺産に登録された和食のバランスの良さを生かせば,体の中から健康墳進に役立つ。

6 ちょっとした外出をマイカーから自転車や公共機関に切り替えれば,歩く距離も增えて健康にも役立つ。 ラベルチェックで産地を磼認し、近くで取れた新鮮な食材を用いれば、健康にも役立つ。

8 ホットカーペットの下に断熱シートを敷くと瑴が逃げないのて暖かく過ごせる。

8020 (80葴に20本の㐘) を目標に、正しい㐘磨きで健康な㐘を長持ちさせることができる

湯船につかって体の芯からあったまれば,血液の流れがよくなり免疫カが高まって, 病気を防ぐのに役立

冬の給湯温度設定は高くしがちだが、洗い物は 38 度で十分、この温度なら手荒れも防げる。 口角をきゅっとあげるのを1日30回，1週間続けると表情が变わり上手なスマイルが出来るようになる。

気流が生じない床䝢房などを上手に使って暖かくすると、睡眼效率も上がって、良い睡眠と「キレイ」につ ながる

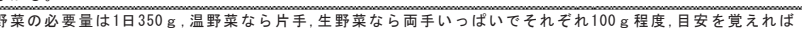
上手に野菜が取れる。

手洗い後はしっかり水気を拭き,クリームを治るときには手をグーにして、しわの間までしっかり治ると手 荒れを防げる。

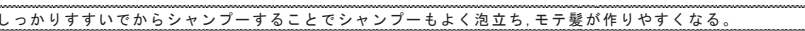

グリルを使って揚げ物のあたため直しをすると、油が程よく落ちて手軽でヘルシーになる

3葴若返る肌の手入れは, 基本に忠実に污れを落とし、化粧水などで水分を補給し、乳液などで膜を作る

1日1万歩歩けば、筋肉の $70 \%$ がある下半身が錪えられ、背筋を伸ばし大股でさっそうと歩くとスタイルも くなる。

ミストサウナ浴は,シャワー浴より毛穴が広がり活れが取れやすく,頭皮の血行も促進されて頭皮ケアにも 役立つ。

通常の混合水栓は, 真ん中にしておくと水とお湯の混合水になるので, お湯と水はしっかり使い分けるよう にする。

お風呂を沸かすときや入浴後は，蓋をすることでお湯が椧めにくく節約にもなる

ジャワー1分で12リットルもお湯を使うので,シャワー時間を短くすれば大幅な節約になる。

セーター1枚で2度の効果があるので,少し厚着をして暖房設定温度を下げれは、大幅な節約が可能になる。

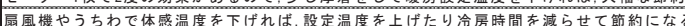

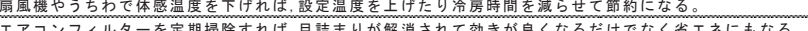

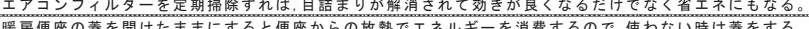

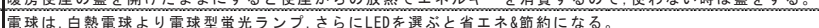
管

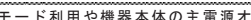
でも省エネになる。

10カーナビやスマートフォン等で交通渉滞情都をチェックし道を選杓すると，時間とガソリンの節約になる。

風上㑡の空は細く、風下側の空を大きく開けると，風が強く感じられて涼しくなる

フローリングワイパーを使うと、ほこりが立たずに手軽に掃除ができる

洗面所や台所にハンドタオルを用意し、ちよっとした污れをすぐに拭き取るようにすれば,ひどい活れにな らないので週に1度の掃除が簡単になる。

家で使わない割り箬やスプーン、レジ俄、粗品などはもらわず，無䭾なものをため込まなければ家を快適に保 $\tau$ 子。

野莱の食へられる部分は切り方をエ夫して全部利用すれば、こみも少なくご搭ても楽になる。

生ごみをぬらさずに新聞やチラシで作ったごみ入れに捨てれば,水分が早く蒸発するのでこみの量が削蔵で きて, 柍いも少なく快適になる。 助かる

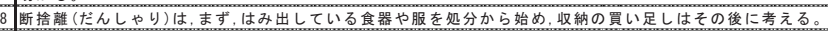
9 リビングルームを床暖房にすると、埃もたたないので快適に過こせるだけたでなく、家族が集まるようにな 夏は日差しをよけるためにレースのカーテンやブラインドを下ろし、冬は長めのカーテンで椧気を防ぐこと で快適に過ごすことができる。 


\title{
STUDY ON MODELING OF THE CONSCIOUSNESS, BEHAVIOR AND DESIRED INFORMATION OF OCCUPANTS IN RELATION TO ENERGY SAVING
}

\author{
Hiroto ABE ${ }^{* 1}$, H.B. RIJAL ${ }^{* 2}$, Kazuaki BOGAKI*3, \\ Masanori SHUKUYA ${ }^{* 4}$ and Ayako MIKAMI*5 \\ ${ }^{* 1}$ Grad. Student, Graduate School of Environmental and Information Studies, Tokyo City University \\ ${ }^{* 2}$ Prof., Faculty of Environmental Studies, Dept. of Restoration Ecology \& Built Environment, Tokyo City University, Dr.Eng. \\ ${ }^{*} 3$ Prof. Emeritus, Tokyo City University, Dr.Eng. \\ ${ }^{*}$ Prof., Faculty of Environmental Studies, Dept. of Restoration Ecology \& Built Environment, Tokyo City University, Dr.Eng. \\ ${ }^{* 5}$ Chief Editor, Tokyo Gas Co., Ltd., Ph.D.
}

Energy use is made by residents, not by buildings. Therefore, how much of energy saving effect is possible by residents' behavior must be important. But at least in Japan, it has not yet been made clear. In recent years, it is expected to achieve energy saving effect by installing home - electric appliances embedded network system. There are some research works trying to find out the motives of residents in relation to the energy-saving behaviors. These trials aim at establishing a new way of stimulating the residents' consciousness that leads to the reduction of energy use.

However, the information to be given in these trials is focused on energy saving alone. Since the residents do not live for energy saving alone, the given information with too much focus on energy saving, but not necessarily well-connected with their life styles, could lead to these trials being not lasting long enough.For this reason, how to achieve energy-saving effects without conscious behavior of "energy saving" is one of the important problems to be tackled with. Therefore, we hypothesized that in order for residents to take energy-saving actions, if the information to be provided is connected well with the residents' most concerned problems and wishes in their daily life, If the information associated with energy saving is embedded in those pieces of information, it may be possible to have them take long lasting actions. Here in this research, we conducted a questionnaire survey on the residents' interests and lifestyle and made on analysis to figure out how the energy saving related consciousness, practice, and willingness are connected with each other. With this analysis, what kind of information is to be given to the residents in order to realize a long-lasting action for energy saving.

We have found the following results:1) If the information to be given is directly related to the problems and wishes of the residents, then, it is likely to be effective. If the level of recognition is high, the level of behavior and the willingness to acquire information are also high. If the level of recognition is low, but behavioral motivation is high, then motivation to acquire information is found high. 2) Women have higher levels of recognition, behavior and willingness to acquire information. It was confirmed that the willingness of men taking actions is also high. Therefore, there is a possibility that men can also be expected to start behavior provided that appropriate information is given. The contents of information to motivate women is closely related to their lives. Those for men need to be in association with their interest. 3) The levels of recognition and behavior tend to be higher as the age increases. The motivation of behavior is higher in younger people. The level of willingness to acquire information becomes lower as the age is over 60 years. There is almost no difference between ages with respect to the desire of information. 4) Residents with children have higher recognition and behavior than those without children. Residents without children have slightly higher motivation of behavior, more willing to acquire information than those with children. The provision of information to residents without children is highly effective.

It has become clear that the information in relation to the problems to be solved or the willingness for making their levels of life higher is likely to let the respondents take actions. Those pieces of information should be implemented with information with respect to energy saving. If such an implementation is made rationally, then it can be expected that the essential energy-saving effect is achieved with appropriate long-lasting behaviors. 